\title{
体幹加速度を用いた歩行の質評価と跛行患者の歩容解析
}

米田 昌弘 ${ }^{* 1}$, 福田 寛二*2, 池㴊 充彦*3, 井上 優 ${ }^{* 4}$, 大井 通正 ${ }^{* 5}$ 三橋 亜由美 ${ }^{* 6}$ ，西田 篤司 ${ }^{* 6}$, 松田 昌弘 ${ }^{* 6}$, 村上 昌宏 ${ }^{* 6}$ ，系数 万紀 ${ }^{* 2}$

\section{Gait quality evaluation by the spectral analysis results of trunk acceleration and gait analysis of lame patients based on the gait quality index}

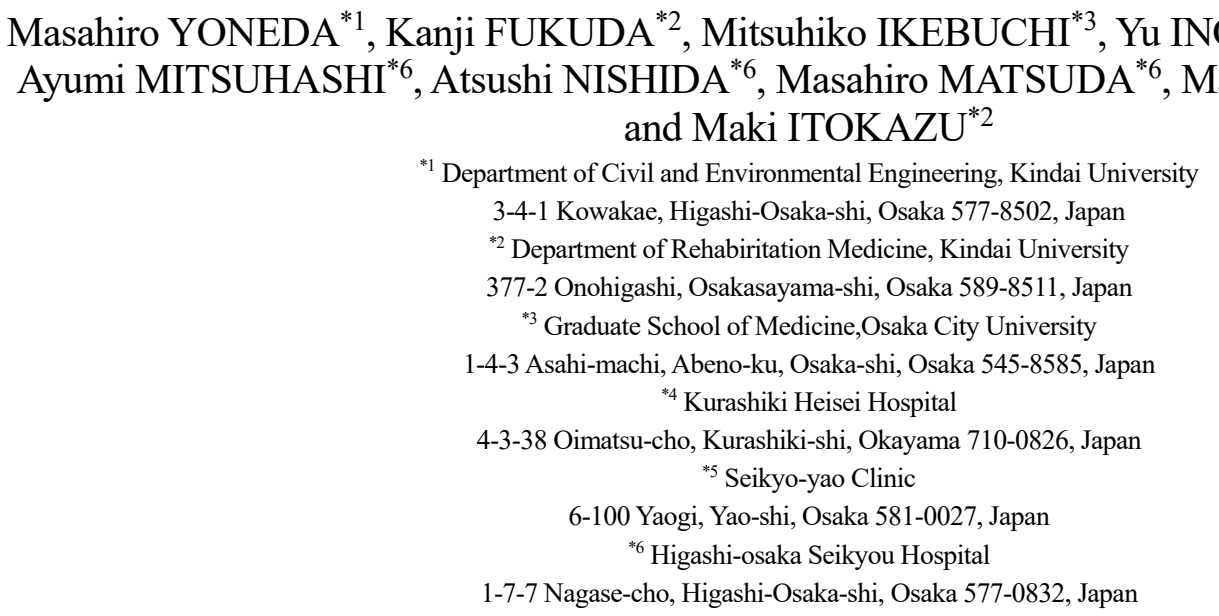

Received: 11 March 2020; Revised: 22 April 2020; Accepted: 12 May 2020

\begin{abstract}
The purpose of this study is to investigate the gait improvement for lame patients based on the gait quality index estimated by the spectral analysis results of trunk acceleration. The gait quality index (GQI) is defined as the power spectrum ratio of the total value up to $10 \mathrm{~Hz}$ to that of the $f w$ component in the vertical direction where $f w$ is the pace frequency. The hemiplegic patients, patients after total hip arthroplasty, patients with femoral fractures, patient with anterior cruciate ligament injury and Parkinson's disease patients were selected in this study. Dynamic load factor (DLF) corresponding to the vertical walking force is also calculated using power spectrum density for time history trunk signals measured by the accelerometers. When the correlation between DLF and GQI was plotted, it was found that the gait quality index GQI was clearly improved (numerically reduced) for all lame patients as the increase of DLF due to the improvement of the gait. Based on these results, it was confirmed that the value of GQI in the vertical direction was the useful index in order to evaluate the gait improvement for all lame patients.
\end{abstract}

Keywords : Gait analysis, Lame patients, Accelerometer, FFT analysis, Gait quality index

\section{1. 緒言}

跛行患者の歩容改善効果を評価するため，今までにも様々な歩容解析が医療分野でなされているが，最も研究 報告が多いのは 3 次元動作解析装置と床反力計を用いた手法である（南角他，2005）（Picelli et al.,2010（重枝他，

No.20-00080 [DOI:10.1299/transjsme.20-00080], J-STAGE Advance Publication date : 20 May, 2020

${ }^{* 1}$ 近畿大学理工学部 社会環境工学科 (下577-8502 大阪府東大阪市小若江 3-4-1)

*2 近畿大学医学部 リハビリテーション医学教室（テ589-8511 大阪府大阪狭山市大野東 377-2)

*3 大阪市立大学医学部 リハビリテーション医学教室（テ545-8585 大阪府大阪市阿倍野区旭町 1-4-3）

*4 倉敷平成病院 (下710-0826 岡山県倉敷市老松町 4-3-38)

*5 医療生協八尾クリニック（テ581-0027大阪府八尾市八尾木 6-100）

*6 東大阪生協病院リハビリテーション科（テ577-0832 大阪府東大阪市長瀬町 1-7-7）

E-mail of corresponding author: yoneda@civileng.kindai.ac.jp 
2014）。また，近年では，臨床への応用という観点から，加速度計を用いた歩行分析（田中他，1996）（池㴊他， 2008）も改めて注目されるようになっている，ただし，加速度計を用いたこれまでの歩容解析は，重心加速度や RMS 值の算出ならびにリサージュ図の作成（香川他，2009）などに多用されており，跛行を定量的に診断できる 手法としては未だ確立されていないのが実状であった。このような状況のもと，著者らは，加速度計を用いた歩 行診断に用いる評価指標として, 鉛直方向ではDLF (Dynamic Load Factor の略記), 前後方向では PR (Power spectral Ratio の略記）ないしは GS (Gait Stage の略記), 左右方向では横変位が有用であることを報告している（米田他, 2018）（米田他，2019）。ここに，DLF は日本語では歩行荷重係数と呼ばれ，歩行者の体重に DLF を乗じること で，動的な歩行荷重の大きさ（床面を踏みしめる力の動的成分）を算定できる指標である．また，PR は，左右の 下肢で 1 秒間に床面を踏みしめる回数に相当する成分 (歩調成分) を $f w$ 成分と記した場合, $f w$ 成分に対する $0.5 f w$ 成分のパワースペクトル比である.

ところで，健常者の体幹部（正中）で計測した鉛直方向の加速度波形をスペクトル解析すると，歩調成分（fw 成分）以外に，歩調の 2 倍成分（2fw 成分）や 3 倍成分（3fw 成分）などの高次成分も観測され，個人差はあるも のの, これらの高次成分が適度に含まれる歩行が健常者の “歩行らしさ”に対応する. また，この “歩行らしさ” は “歩行の質” と言い換えることもできる．これに対して，片麻痺患者や人工股関節全置換術後患者では，体幹 部に加速度計を設置しても，左右下肢の動作が非対称であることに起因した成分（歩調の半分に相当する $0.5 f \mathrm{w}$ 成分だけでなく，1.5fwや2.5fw などの成分）が観測されることが知られている（米田他，2018）(米田他, 2019）. それゆえ，歩調成分に対するその他の成分割合を定量化できれば，健常者と跛行患者の歩容を識別できる可能性 があると考えられる，ただし，小刻み歩行を行うパーキンソン病患者をイメージすればわかるように，加速度波 形のパワースペクトルから，歩調以外の成分をそれぞれ個別に識別するのは困難な場合も予想される.

そこで，本研究では，体幹部で測定した加速度波形（鉛直方向）のパワースペクトルを用いて，歩調成分（fw 成分）の值に対する $10 \mathrm{~Hz}$ までの合計值を, “歩行らしさ”すなわち “歩行の質”を表す指標と定義した. また， 片麻痺患者, 人工股関節全置換術後患者, 大腿骨骨折患者, 前十字勒帯損傷患者, パーキンソン病患者の歩行実 験結果から, 歩行の質を表す指標とDLF（床面を踏みしめる動的な力を表す係数）の相関関係を図化して整理し たところ，歩容の改善とともに歩行の質を表す指標は明らかに改善（数值的には低減）する結果が得られた。こ の知見は，加速度計を用いて跛行患者の歩容改善を客観的に評価する上できわめて有用であると考えられ，ここ にその検討結果を報告する.

なお，歩行と歩容の使い分けについて，本文では，両下肢による移動を意味する場合には歩行を，歩行時の姿 勢や動作などの特徴を表す場合には歩容を用いることとした.

\section{2. 歩行荷重係数 DLF}

片麻疩患者や人工股関節全置換術後患者では，床面を踏みしめる力の増加，左右下肢に起因した動作の重複と 振幅差の低減，横変位の減少が生じれば，歩容が改善したと考えられる（米田他，2018）（米田他，2019）。これ ら3つの評価項目のうち, 最も重要な指標は床面を踏みしめる力である. 床面を踏みしめる力は床反力計を用いれ ば測定できるが，床反力計は装置そのものが高額であることに加え，一般に計測や解析に長時間を要すること， 測定データも動作解析の専門家以外には直感的に理解しにくいなど, 臨床面での普及を妨げる最大の因子になっ ているとの指摘もなされている (加賀谷他, 2010). このようなことから, 著者らは加速度計の鉛直方向波形から, 床面を踏みしめる力（鉛直歩行荷重）を算定する手法を提案している（米田，2011）。一方，本研究では，“歩行 らしさ”すなわち “歩行の質” を表す指標を新たに定義して歩行診断に適用するが，予備検討の結果，この指標 はDLFと明確な相関関係が認められた，そこで，本章では，歩行の質を表す指標との関連性が高い歩行荷重係数 DLFについて簡単に記述することとする.

歩道橋では, 歩行者が通行すると共振現象で利用者が不快に感じるような大きな振動が生じることがある. そ れゆえ, 橋梁振動の分野では, 共振現象に最も関与寸る歩調（1秒間あたりの歩数）成分について, 歩行荷重を算 出する研究が従来から実施されている（Dallard et al.,2001）（米田，2011）（米田，2013）。このうち，スペクトル 解析結果を用いる手法について以下に述べる.

振幅を $a$, 周波数を $f($ 円振動数が $\omega$ ) として正弦波を 
Yoneda, Fukuda, Ikebuchi, Inoue, Oi, Mitsuhashi, Nishida, Matsuda, Murakami and Itokazu,

Transactions of the JSME (in Japanese), Vol.86, No.886 (2020)

$$
y=a \sin \omega t=a \sin 2 \pi f t
$$

のように表し, 有限長のデータが無限に繰り返すことを前提としたFFT(Fast Fourier Transformの略記)でスペクト ル解析すれば，理論上，周波数 $f$ に対忘するパワースペクトル $P_{f}$ は，次式で与えられる（米田，2011）.

$$
P_{f}=a^{2} \times \frac{T}{2}
$$

ここに，Tは波形の継続時間であり，データ個数を $N$ ，サンプリング時間を $\Delta t$ とた場合， $T=N \times \Delta t$ となる.ただ し，データ個数を2の累乗個とするために後続の0を追加した場合は，後続の0を除いた時間となる.

それゆえ，fw成分のパワースペクトル $P_{f}$ （ピーク值を含む連続した上位4点の合計值）と波形の継続時間 $T$ を式 (2)に代入すれば，一様な正弦波と仮定した歩行者の体幹加速度 $a$ を逆算できる（米田，2016）。そして，この体 幹加速度 $a$ を重力加速度 $g\left(\fallingdotseq 9.81 \mathrm{~m} / \mathrm{s}^{2}\right)$ で除すれば，Dynamic Load Factor（以下，DLFと記す）を算定することが できる．参考までに， DLF(= $a / g)$ が算定できれば，歩行荷重の動的成分 $F_{d}$ は次式のように表示できる.

$$
F_{d}=m \times a \sin 2 \pi f t=\frac{W}{g} \times a \sin 2 \pi f t=W \times \frac{a}{g} \sin 2 \pi f t=W \times \mathrm{DLF} \times \sin 2 \pi f t
$$

ここに, $m$ は歩行者の質量, Wは歩行者の体重である.

なお，図 1 は，過去に実施された実験報告（小堀他，1974）をもとに床反力の動的成分（床反力の測定值から 体重分を除去した成分）と慣性力（体重 $W \times$ DLF）を対比した先行研究結果（米田他，2019）であるが，この図 からも両者は比較的よく対応していることがわかる.

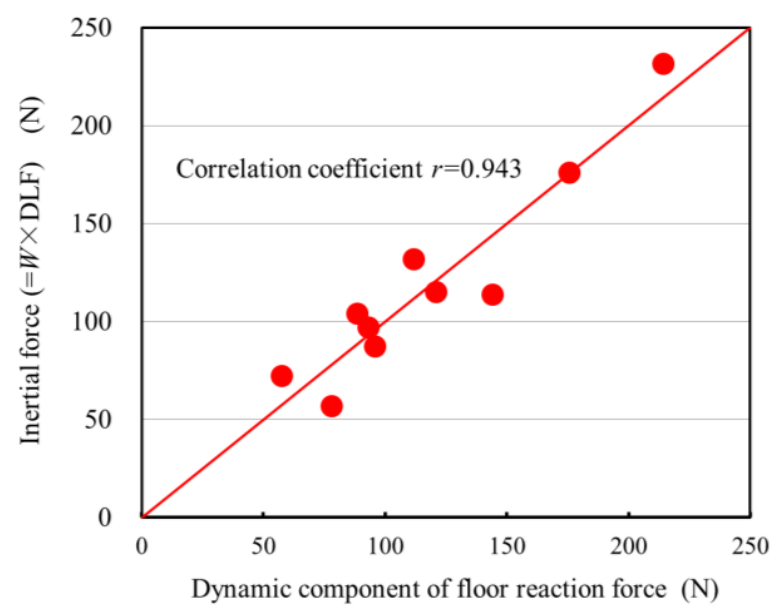

Fig.1 Relationship between dynamic component of floor reaction force and inertial force. It can be seen from this figure that the inertial force corresponds well with the dynamic component of floor reaction force. This figure is quoted from (Yoneda et al.,2019).

\section{3. 歩行の質を表す指標}

\section{$3 \cdot 1$ 歩行らしさ}

本章で提示する健常者と片麻痺患者およびパーキンソン病患者の歩行実験は，近畿大学大学院（大阪府東大阪 市小若江 3-4-1)，東大阪生協病院（大阪府東大阪市長瀬 1-7-7），倉敷平成病院（岡山県倉敷市老松町 4丁目 3-38） の倫理委員会で承認を得た上で実施している. 
Yoneda, Fukuda, Ikebuchi, Inoue, Oi, Mitsuhashi, Nishida, Matsuda, Murakami and Itokazu, Transactions of the JSME (in Japanese), Vol.86, No.886 (2020)

まず，男性健常者（年齢 22 歳，身長 $175 \mathrm{~cm} ，$ 体重 637N）が $10 \mathrm{~m}$ の直線距離を快適自由歩行した場合を対象と して, 正中で計測した鉛直方向の加速度波形を FFT でスペクトル解析した. 加速度計の設置位置は正中（腰背部） であり, サンプリングタイムは $0.005 \mathrm{~s}$ である. 解析で得られたパワースペクトルを図 2 に示す. 図 2 からわかる ように，健常者が歩行した場合，鉛直方向には，歩調である $f w$ 成分に加え， $2 f w$ 成分（歩調の 2 倍成分），3fw成 分 (歩調の 3 倍成分), $4 f w$ 成分（歩調の 4 倍成分）などの高次成分が観測されていることがわかる. また，健常 者では, $10 \mathrm{~Hz}$ 以上のパワースペクトルは非常に小さいこともわかる.

一方, 図 3 は女性の片麻痺患者（年齢 69 歳，身長 $148 \mathrm{~cm}$, 体重 $497 \mathrm{~N}$ ）を対象として, 鉛直方向の加速度波形 を同様にスペクトル解析した結果である。この図から，片麻瘏患者では，歩調の fw 成分以外に，2fw 成分， $3 f w$ 成分, $4 f w$ 成分, $5 f w$ 成分や $0.5 f w$ 成分, $1.5 f w$ 成分, $2.5 f w$ 成分, $3.5 f w$ 成分, $4.5 f w$ 成分, $5.5 f w$ 成分など, 数多く の周波数成分が混在していることがわかる. 参考までに, $0.5 f w$ 成分は左右下肢が非対称な動作をすることによっ て観測される成分である. また，1.5fw，2.5fw，3.5fw，4.5fw，5.5fw などの成分は，左右腰部で逆位相になる成分 (やじろべえのような動きをする成分）であり，正中に加速度計を設置した場合，健常者では観測されないこと が知られている（米田，2015）.

ところで, 片麻疩患者が歩行リハビリテーションによって, 発症前と同じ歩行能力（健常者としての歩行能力） を取り戻すことができたとすれば, 図 2 とよく似たスペクトル特性を呈すると考えられる.すなわち, $0.5 f w, 1.5 f w$, $2.5 f w ， 3.5 f w ， 4.5 f w ， 5.5 f w$ などの成分が消失し，fw 成分とそれより小さな $2 f w ， 3 f w ， 4 f w$ などの高次成分が適度 の割合で混在する．そこで，健常者が歩く場合の“歩行らしさ”を“歩行の質”とみなして，

$$
\mathrm{GQI}=\frac{10 \mathrm{~Hz} \text { までのパワースペクトルを合計した值 }}{f w \text { 成分だけのパワースペクトル }}
$$

と定義すれば, 前章で示した歩行荷重係数 DLF と併用することで, 跛行患者の歩容改善を評価できると推察され る. なお，歩行の質を表す指標 GQI は, Gait Quality Index の略語である. また, 0.5fw，1.5fw，2.5fw，3.5fw，4.5fw， $5.5 f w$ などの成分だけでなく，2fw，3fw，4fwなどの成分までも含めて考慮したのは，高次成分になるにしたがっ て, 次数の識別が困難になるためである. 実際, 図 4 はパーキンソン病患者の解析事例（体幹部鉛直方向成分の パワースペクトル）を示したものであるが, この図からも高次成分の次数判定は難しいことがわかる. ちなみに, 歩行の質を表す指標 GQI の上限周波数（10Hz）は，2 歩/秒で歩く一般の健常者を想定すれば，歩調の 5 倍に相当

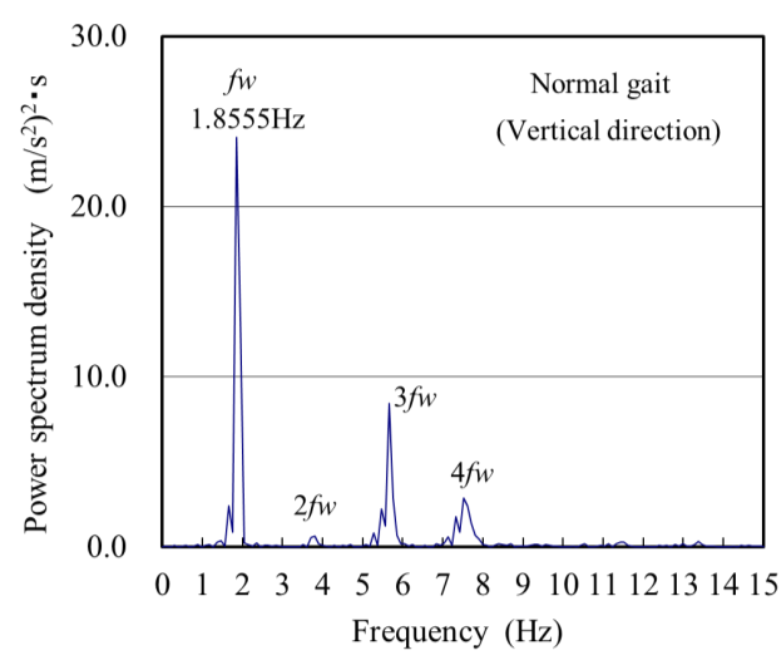

Fig.2 Power spectrum density by FFT analysis. In case of normal gait, higher-order components such as $2 f w, 3 f w$ and $4 f w$ are observed in addition to the $f w$ component where $f w$ is the pace frequency.

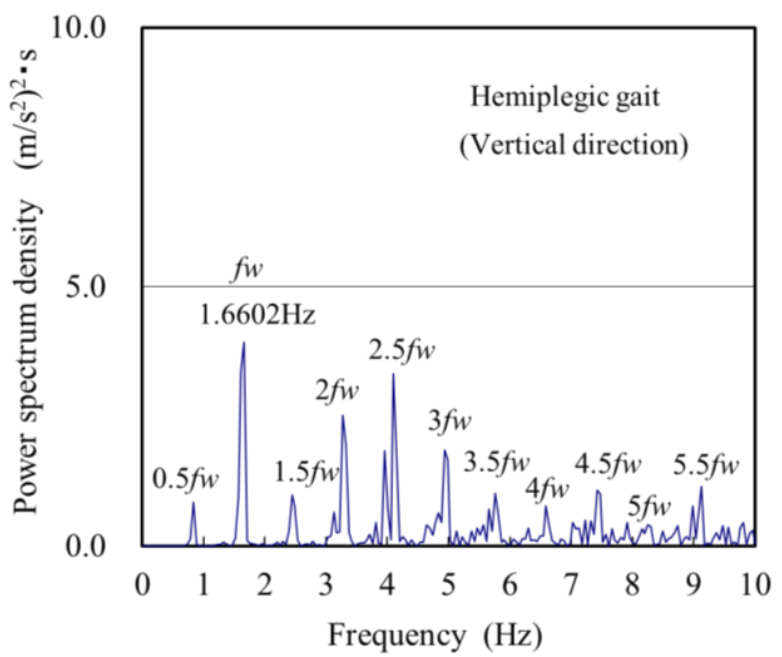

Fig.3 Power spectrum density by FFT analysis. In case of hemiplegic gait, many frequency components such as $0.5 \mathrm{fw}$, $1.5 f w, 2 f w, 2.5 f w, 3 f w, 3.5 f w, 4 f w, 4.5 f w, 5 f w$ and $5.5 f w$ are mixed in addition to the $f w$ component. 


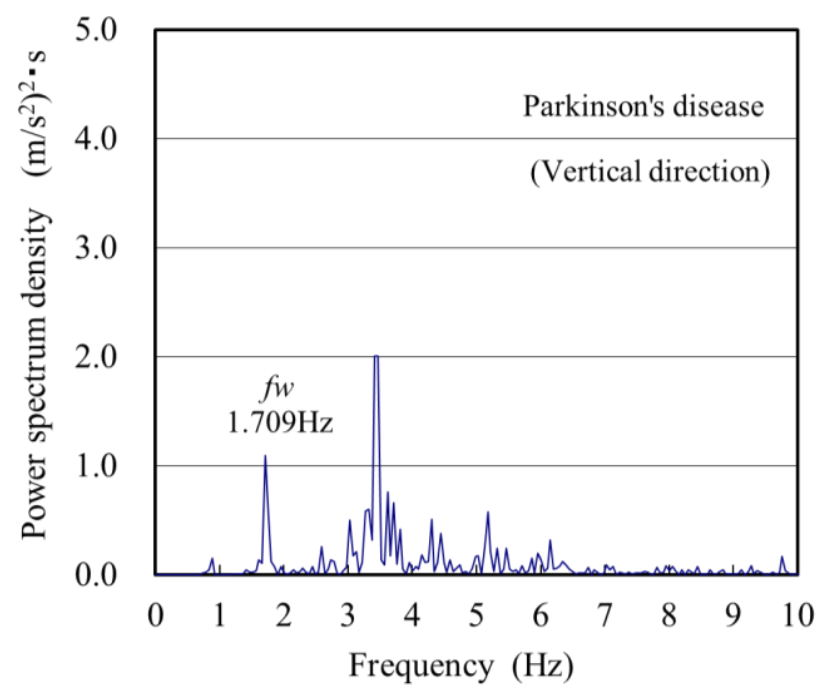

Fig.4 Power spectrum density by FFT analysis for Parkinson's disease patient. It can be seen from this figure that it is difficult to determine the order of higher components.

する $5 f w$ の值 $(10 \mathrm{~Hz})$ に対応する，また，図 2 を用いてすでに説明したように，健常者では $10 \mathrm{~Hz}$ 以上のパワー スペクトルが非常に小さく, $10 \mathrm{~Hz}$ を上限周波数として GQI を算定しても大きな誤差は生じないと考えられる.

パワースペクトルは，その名の通り，歩行にともなう加速度のパワー（エネルギー）を表すものである．それ ゆえ，跛行の改善にともなって GQI が減少寸れば，高次成分のパワー（エネルギー）が減少して主成分である $f w$ 成分のパワー（エネルギー）が増加したと解棌できる.

\section{$3 \cdot 2$ 健常者の測定値}

男性健常者 4 人（年齢は全員が 22 歳）と女性健常者 10 人（平均年齢 $24.5 \pm 2.77$ 歳）が快適自由歩行した場合 の GQI を算定した．DLF の大きさに対する GQI の関係を図 5 に示す．なお，歩行荷重係数 DLF は健常者の最低 值が 0.1（米田他，2018），歩道橋の設計に用いる推奨值（2 歩秒で歩いた場合の值）が 0.4 であることが知られ ている（梶川，1982）。それゆえ，図 5 から, 個人差によるばらつきは認められるものの, 健常者が快適歩行した 場合（DLF が 0.1 から 0.4 の場合），歩行の質を表す指標 GQI は $1.3 \leqq G Q I \leqq 2.0$ 程度であると推察される.

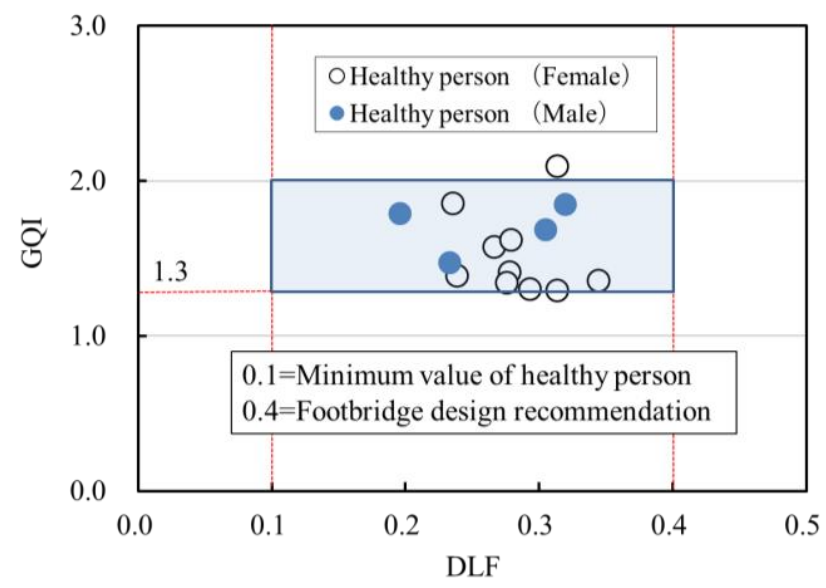

Fig. 5 Relationship between DLF and GQI in the vertical direction. It is presumed that the index GQI is about $1.3 \leqq \mathrm{GQI}$ $\leqq 2.0$ when a healthy person walks comfortably (when DLF is 0.1 to 0.4$)$.

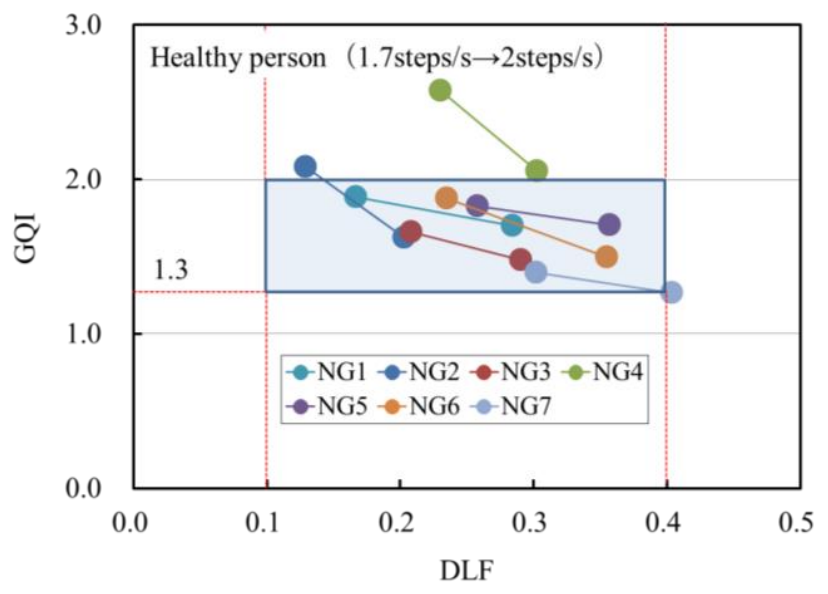

Fig. 6 Relationship between DLF and GQI in the vertical direction when a healthy person walks at $1.7 \mathrm{steps} / \mathrm{s}$ and 2.0 steps /s. It can be seen from this figure that the value of GQI decreases as DLF increases. 
ただし，DLF は歩調（1 秒間の歩数）によって変化する．そこで，新たな健常者 NG1-NG7 の 7 人（21.0 00.93 歳）を対象として，電子メトロノームの発信音に合わせて，1.7 歩/秒と 2.0 歩/秒で歩行した場合の GQI を算定し た. その結果を図 6 に示すが, この図から DLF が大きくなるにしたがって GQI の数值が低下することがわかる. それゆえ，床面を踏みしめてしっかり歩くと（DLF が大きくなると），健常者でも歩調成分以外の成分が相対的 に低下寸る（歩調成分が相対的に増加する）と言える. なお，図 6 には健常者に対する歩行の質領域も付記して いるが，健常者 NG4 が意図的にゆっくり歩いた場合（1.7 歩/秒）を除き，本研究で想定した領域（DLF が 0.1 か ら 0.4 における GQI は $1.3 \leqq G Q I \leqq 2.0$ 程度）は概ね妥当であることがわかる.

なお，著者らの知る限り，加速度波形のパワースペクトルを用いて GQI を算定した事例は報告されていない. ただし，歩調成分に加え，高次成分の DLF がわかれば GQI の概略值を試算することは可能である．たとえば, DLF に関する既往研究(Murray et al.,2003)では, 1 次が 0.5(1.6-2.2Hz), 2 次が 0.2(3.2-4.4Hz), 3 次が 0.1(4.8-6.6Hz), 4 次が 0.05(6.4-8.8Hz) という值が提示されており，この值を用いて GQI を試算すると GQI=2.2 となる. また，他 の文献(Mårtensson and Nilsson,2014)では, 1 次が $0.37 \times(f w-1.0), 2$ 次が $0.1,3$ 次が $0.06,4$ 次が $0.06,5$ 次が 0.06 という DLF 值が提示されており， $f w=1.7 \mathrm{~Hz}$ を代入して GQI を試算すれば GQI=1.31 となる．高次成分の DLF は 歩調成分に比べて個人差によるばらつきが非常に大きい（米田，2013）が，既往の DLFに関する研究結果を用い て試算した GQI は，本研究で提示した数值と概ね同程度であったことを述べておく。

\section{4. 跛行患者の歩容解析}

\section{$4 \cdot 1$ 片麻㾝患者}

片麻痺患者の歩行実験は, 近畿大学大学院（大阪府東大阪市小若江 3-4-1） と東大阪生協病院（大阪府東大阪市 長瀬 1-7-7）の倫理委員会で承認を得た上で実施した. 片麻瘏患者の歩行では，左右下肢の動作が非対称になり， 床面を踏みしめる力も低下寸るという特徵がある．このことも踏まえ，片麻痺患者の体幹部で計測した鉛直方向 の加速度波形（サンプリングタイムは 0.005s）をスペクトル解析し，DLF と GQI の関係を算出した．その結果を 図 7 に示寸. なお，この図には，健常者が快適歩行した場合の領域も付記している.

被験者である HP1 と HP3 の実験結果はすべて杖歩行で，凡例中の数值は実験を実施した月日を表している. また, HP2 の歩行実験は 1 回目 (4-24) が U 字型歩行器を用いた歩行で, 2 回目(5-9) と 3 回目(5-24)は独歩である. これら 3 人の歩容に対して, 理学療法士による目視観察では, 経時にともなって左右下肢の非対称性や歩行時の バランス（健全性）が改善していると判断されたが，この判断は図中に示した DLF-GQI の相関図ともよく対応

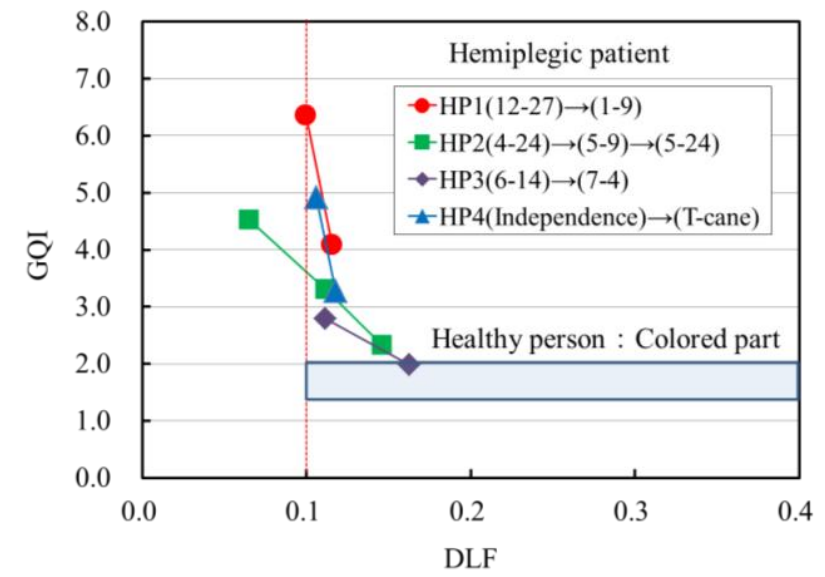

Fig. 7 Relationship between DLF and GQI in the vertical direction when a hemiplegic patient walks comfortably. It can be seen from this figure that the value of GQI decreases as DLF increases with the gait improvement.

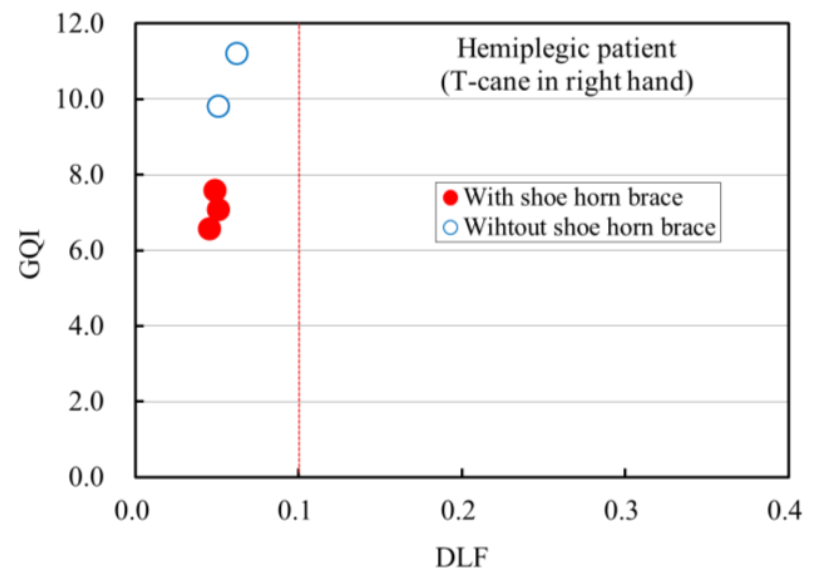

Fig. 8 Relationship between DLF and GQI in the vertical direction for a hemiplegic patient with and without the shoe horn brace. It is confirmed from this figure that GQI reduction (gait improvement) is surely achieved when the shoe horn brace is installed. 
Yoneda, Fukuda, Ikebuchi, Inoue, Oi, Mitsuhashi, Nishida, Matsuda, Murakami and Itokazu, Transactions of the JSME (in Japanese), Vol.86, No.886 (2020)

する結果となっている，一方，HP4（年齢 64 歳，身長 $170 \mathrm{~cm}$, 体重 621N）は病棟内杖歩行自立レベルの患者で, 独歩自立を目指している，そこで，同じ日時に独歩と杖歩行（T-cane 歩行）について加速度計を用いた歩容計測 を行い，DLF と GQI の関係を算定した．その結果は図中に山印で記しているが，具体的に記述すれば，独歩では $\mathrm{DLF}=0.106, \mathrm{GQI}=4.914$ だった数值が，T-cane 歩行では $\mathrm{DLF}=0.118 ， \mathrm{GQI}=3.272$ と算出された．すなおち，独歩 であっても床面を踏みしめる力（DLF の大きさ）は T-cane 歩行と比較して $10 \%$ 程度しか低下していないが，歩行 の質を表す指標 GQI は独歩で $4.914 / 3.272 \doteqdot 1.50$ 倍（歩行の質は $3.272 / 4.914 \doteqdot 0.67$ 倍の低下）であり，歩行特性は T-cane 歩行の方が良好であったと評価できる.

一方，DLF はほとんど変化しないが，GQI だけが明確に低減した事例も認められたＨP5（年齢 67 歳，身長 $165 \mathrm{~cm}$ ，体重 $551 \mathrm{~N}$ ）は病棟内杖歩行自立レベルの患者であり，左下肢にシューホーンブレースを装着した場合と 装着しなかった場合のそれぞれについて，同じ日に歩行実験（右手に 1 点杖を持った T-cane 歩行）を実施した. ここに，シューホーンブレースとは，プラスチック製の一体型短下肢装具のことであり，脳卒中片麻疩患者の歩 行時における支持性を高めるために多く使用されている. 実験回数はシューホーンブレースを装着した場合が 3 回であり，装着しなかった場合が 2 回である.HP5 に対する DLF と GQI の関係を図 8 に示す。この図からわか るように，シューホーンブレースの有無にかかわらずDLFには大きな相違は認められないが，シューホーンブレ 一スを装着した場合は確実に GQI の低減（歩容の改善）が認められる．理学療法士による目視観察では，シュー ホーンブレースの装着で左下肢の動作が改善していると判断されたが，この見解はここに示した解析結果とも一 致する，それゆえ，GQI は下肢装具の選定作業において，きわめて有用な指標になり得ると考えられる.

ところで，歩行は床面を踏みしめて前方に移動する動作であることから，鉛直方向と前後方向で測定した加速 度波形には何らかの相関関係があると考えられる. そこで, 体幹の前後方向加速度に対しても GQI を算出し, DLF との関係を整理することとした．その結果を図 9 に示す．この図から，前後方向の加速度波形に対して GQI を算出しても, DLF の増加にともなって GQI が低下寸る（歩容が改善する）という相関が認められることがわか る.ただし，図７と比較すればわかるように，DLFに対する GQI の変化割合は鉛直方向の方が明らかに大きく， 指標としては鉛直方向の GQI を適用した方が有用であると言える.

一方, 加速度計を用いた歩行評価には, 前後方向の PR 值 (= fw 成分に対する $0.5 f w$ 成分のパワースペクトル比) と左右方向の横変位（0.5fw 成分）も有用であることが知られている（米田他，2019）。そこで，それぞれの指標 に対しても，DLF との関連性を整理した，その結果をそれぞれ図 10, 図 11 に示す，これらの図より，歩容が改 善してDLF が増加すれば, PR と横変位も低減 (改善) 寸る傾向にあることがわかる. ただし, PR では HP2 の(5-9)

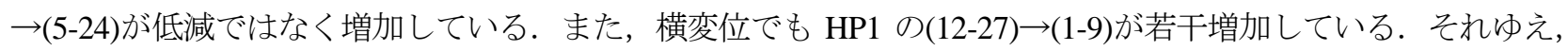
これら 2 つの指標に対する DLF の依存性は, 鋁直方向の GQI と比較して幾分小さく, それぞれ独立の歩行評価

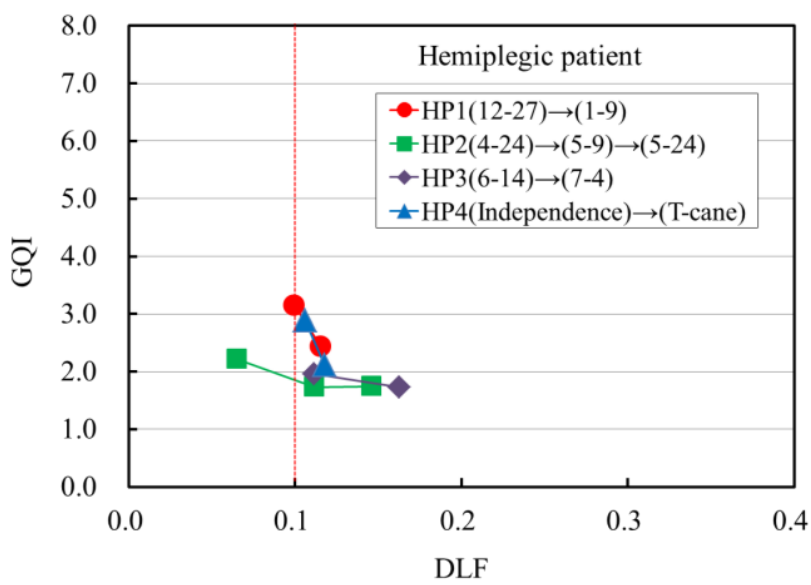

Fig. 9 Relationship between DLF and GQI in the fore and posterior directions when a hemiplegic patient walks comfortably. It can be seen from this figure that the value of GQI in the fore and posterior directions decreases as DLF increases with the gait improvement. But, as can be seen from the comparison with Fig. 7, the change ratio of GQI to DLF is clearly larger in the vertical direction, and it is more useful to use GQI in the vertical direction as an index. 


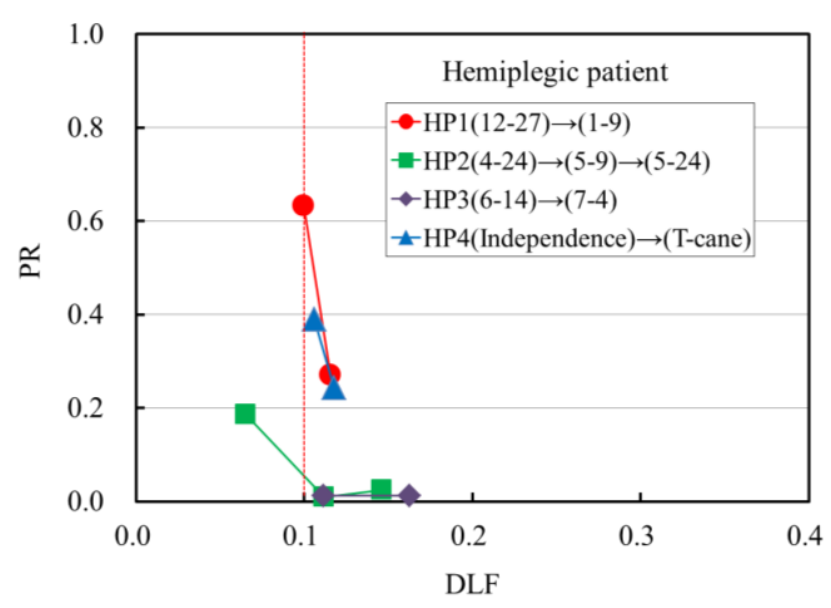

Fig. 10 Relationship between DLF and PR in the fore and posterior directions when a hemiplegic patient walks comfortably, where PR is defined as the power spectrum ratio of $0.5 f w$ to $f w$ component. It can be seen from this figure that the value of PR decreases as DLF increases with the gait improvement except for HP2.

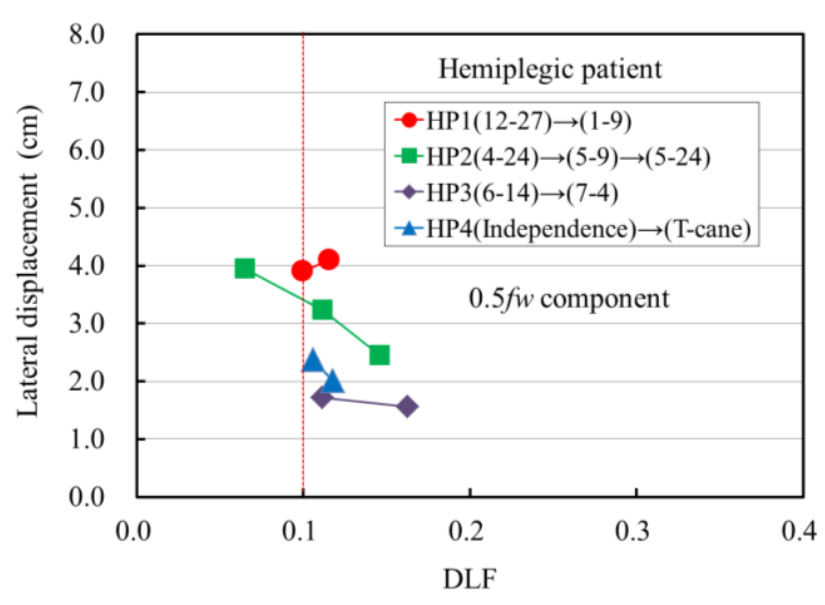

Fig. 11 Relationship between DLF and lateral displacement when a hemiplegic patient walks comfortably. It can be seen from this figure that the value of lateral displacement decreases as DLF increases with the gait improvement except for HP1.

指標として採用寸ればと良いと考えられる.

以上より，動的な歩行荷重係数 DLF（床面を踏みしめる動的な力を表す係数）と歩行の質を表す指標 GQI との 相関図を作成すれば，片麻疩患者の歩容改善をより適切かつ正確に算定できると言える.

\section{$4 \cdot 2$ 人工股関節全置換術後患者}

本節で採用した人工股関節全置換術後患者（Total Hip Arthroplasty の略語を用いて，以下，THA 術後患者と記 す）の歩行実験データは，倫理審査委員会による承認が義務化されていなかった 2006 年 1 月から 2009 年 1 月の 期間に, 大阪市立大学医学部で測定されたものである. ただし, 被験者に対しては, 研究の趣旨と内容, 得られ たデータの取り扱いなどを十分に説明し，同意を得ている.

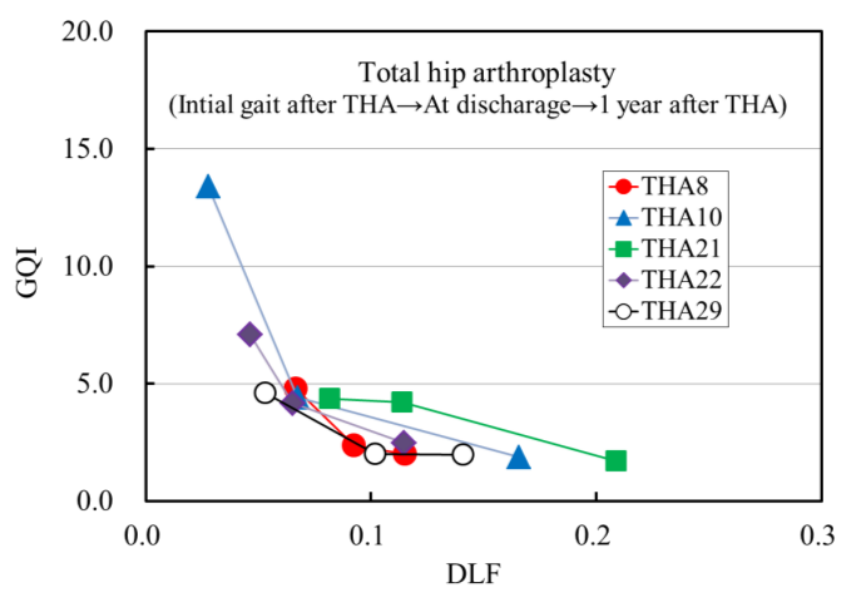

Fig. 12 Relationship between DLF and GQI in the vertical direction when a patient after total hip arthroplasty walks comfortably. It can be seen from this figure that the value of GQI decreases as DLF increases with the gait improvement.

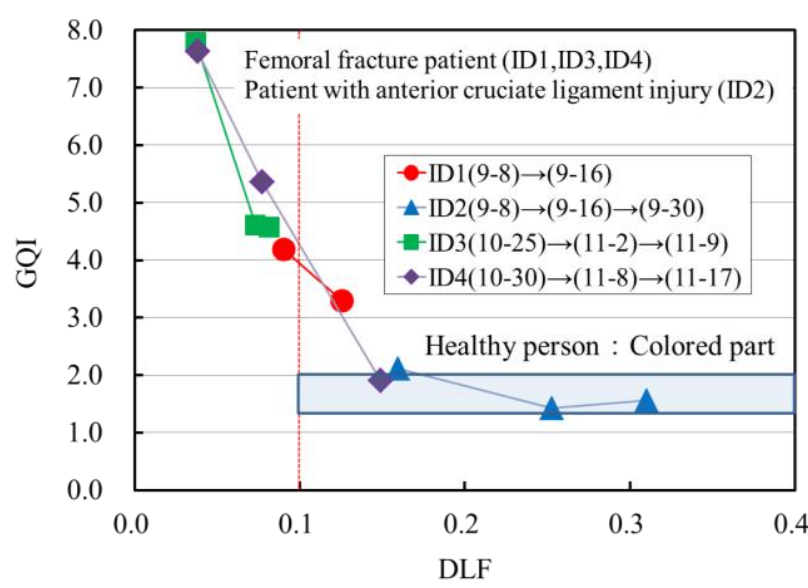

Fig. 13 Relationship between DLF and GQI in the vertical direction for femoral fracture patients and a patient with anterior cruciate ligament injury. It can be seen from this figure that the value of GQI decreases as DLF increases with the gait improvement. 
THA 術後患者の歩行では，術後から十分な期間が経過するまで，左右下肢の動作が非対称になり，床面を踏み しめる力も低下するという特徴がある. このことも踏まえ, 歩行実験は, 手術前, 退院直前, 術後 3 个月 (独歩), 術後 6 ケ月（独歩），術後 1 年（独歩）で実施しているが，本研究では，DLFに明確な相違が認められた歩行開 始（杖歩行），退院直前（杖歩行），術後 1 年（独歩）における実験結果に着目した．なお，入院途中の杖歩行を 計測した術後日数は患者によって幾分異なり，たとえば， 21 番目の患者 THA21 では，歩行開始が術後 7 日，退 院直前が術後 24 日であった.

正中で測定された鉛直方向の加速度波形から，計測開始直後と計測終了直前を除く定常的な測定データを抽出 した後，FFTによるスペクトル解析を実施して，DLFと GQI の関係を算出した．その結果を図 12 に示す．この 図からわかるように, THA 術後患者に対しても, 術後の経時変化とともに DLF が増加すれば, 歩調成分のパワ 一が増加（歩調以外の成分が占めるパワーが低下）し，歩行の質を表寸指標 GQI が順調に改善（数值としては低 減）している．それゆえ，THA 術後患者の歩容改善診断に対しても，DLF と GQI の相関図は有用な指標になり 得ると考えられる.

\section{$4 \cdot 3$ 大腿骨骨折患者と前十字勒帯損傷患者}

大腿骨骨折患者と前十字勒帯損傷患者では，完治するまで左右下肢の動作が非対称になり，床面を踏みしめる 力も低下寸るという特徵がある. 対象とした被験者は 4 人 (大腿骨頸部骨折患者 3 人と前十字靭帯損傷患者 1 人) であり，実験は倉敷平成病院（岡山県倉敷市老松町 4丁目 3-38）の倫理委員会より承認を受けて実施した.

歩行距離は $10 \mathrm{~m}$ であり, 歩行は独歩の快適自由歩行とした. サンプリングタイムは $\Delta t=0.005 \mathrm{~s}$ であり, 鉛直方 向の加速度波形から, 歩行開始直後と歩行終了直前を除く定常的な測定データを抽出した後, FFT でスペクトル 解析し，DLF とGQI の相関図を作成した，その結果を図 13 に示寸．なお，この図には，健常者が快適歩行した 場合の領域も付記している.

図 13 から, 大腿骨骨折患者と前十字勒帯損傷患者であっても, 術後の経時変化とともに DLF が増加すれば, 歩調成分のパワーが増加 (歩調以外の成分が占めるパワーが低下) し, 歩行の質を表す指標 GQI が順調に低減 (改 善）していることがわかる．それゆえ，大腿骨骨折患者と前十字勒帯損傷患者の歩容診断に対しても，DLF と GQI の相関図は有用な指標になり得ると考えられる.

\section{$4 \cdot 4$ パーキンソン病患者}

パーキンソン病患者の歩行実験は，倉敷平成病院（岡山県倉敷市老松町 $4 丁$ 丁目 3-38）の倫理委員会より承認を 受けて実施した．測定方法は，大腿骨骨折患者と前十字勒帯損傷患者の場合と全く同じである.

パーキンソン病患者では，身体のバランスを保つ筋力が低下し，症状が進むと，小刻み歩行（歩幅が狭くなり 腕の振りが小さくなる歩行）や寸り足歩行ならびに加速歩行（前のめりで歩き, 歩いているうちに早足になる歩 行）を行う。また，すくみ足（歩こうと思ってもなかなか一歩が踏み出せず，足が地面に貼り付いたようになる 状態）を呈する場合も知られている。このような異常歩行を呈するパーキンソン病患者の治療法には, 薬剤投与 と脳深部刺激療法（以下, Deep Brain Stimulation の略語である DBS と記す）がある.まず，薬剤投与の有無（Drug の on と off) に着目するため, PD1 の患者に対して, Drug off と Drug on の鉛直方向加速度波形を FFT でスペク トル解析した，その結果を図 14 と図 15 に示寸。これらの図を比較寸ればわかるように, Drug on では, 歩調成 分（fw 成分）のパワーが明らかに増加（歩調以外の成分が占めるパワーは明らかに減少）しており，薬剤投与が 有用であったことがわかる. PD2, PD3, PD4 の患者に対しても同様に FFT でスペクトル解析したところ, 同じ く薬剂投与の有効性が認められた。 そこで，この 4 人の患者に対して，DLFと GQI の関係（Drug off と Drug on の対比結果）を整理した，その結果を図 16 に示寸．この図から，薬剂を投与してDLFが増加すれば，歩調成分 のパワーが増加（歩調以外の成分が占めるパワーが低下）し, 歩行の質を表す指標 GQI が順調に低減（改善）し ていることがわかる.さらに, DBS と薬剤投与した患者PD5 の結果を図 17 に示寸が，この図からも DBS と薬剤 投与による歩容改善を定量的に評価できることがわかる.

以上より, パーキンソン病患者の歩容診断に対しても, DLF と GQI の相関図は有用な指標になり得ると考えら れる. 
Yoneda, Fukuda, Ikebuchi, Inoue, Oi, Mitsuhashi, Nishida, Matsuda, Murakami and Itokazu,

Transactions of the JSME (in Japanese), Vol.86, No.886 (2020)

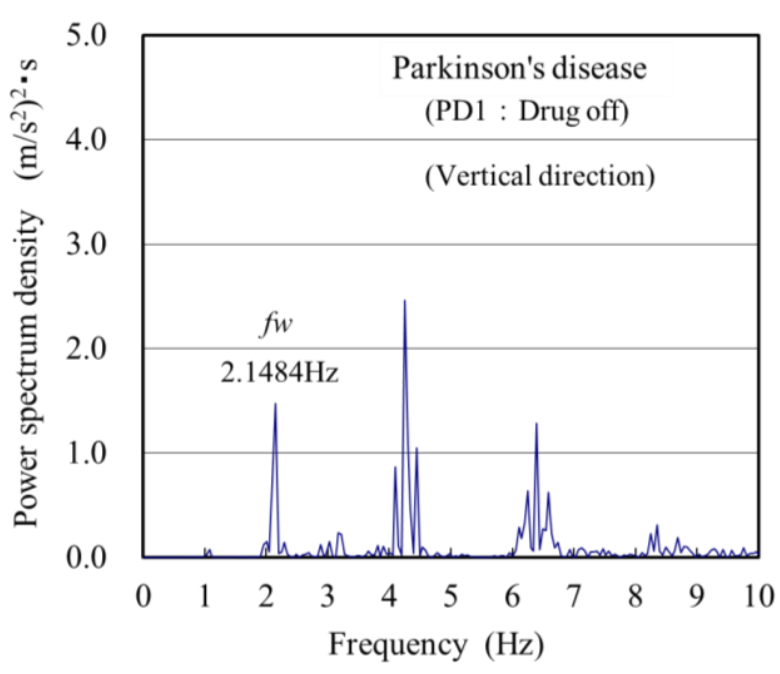

Fig.14 Power spectrum density by FFT analysis for Parkinson's disease patient PD1. In case of Drug off, relatively large higher-order components are clearly observed in addition to the fw component.

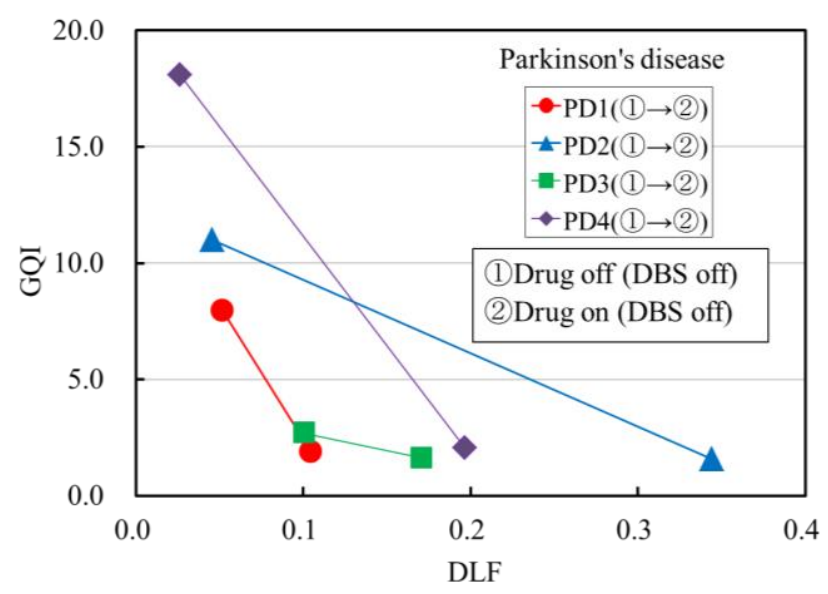

Fig. 16 Relationship between DLF and GQI in the vertical direction when a Parkinson's disease patient walks comfortably. It can be seen from this figure that the value of GQI decreases as DLF increases due to the effect of drug.

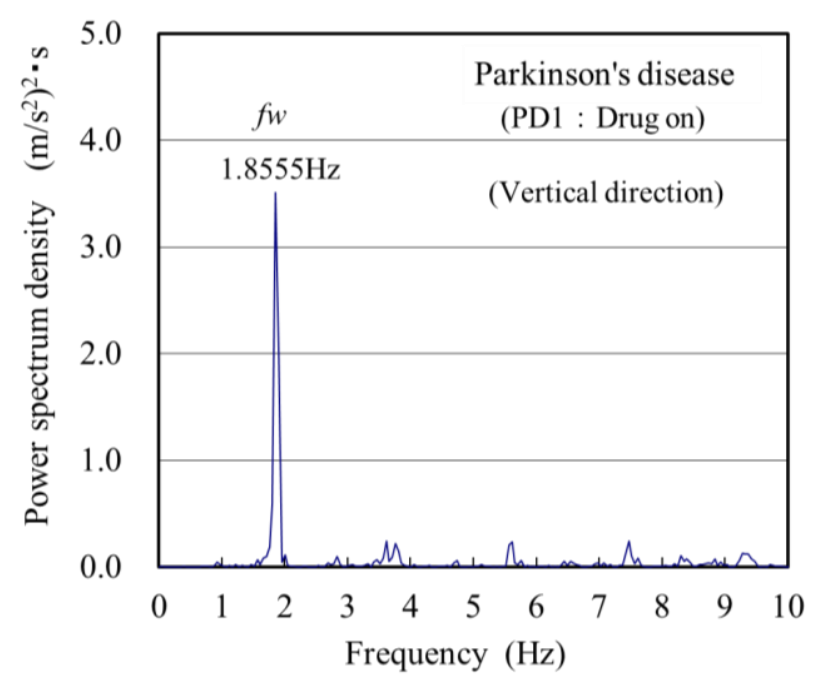

Fig.15 Power spectrum density by FFT analysis for Parkinson's disease patient PD1. In case of Drug on, only relatively small higher-order components are observed in addition to the $f w$ component.

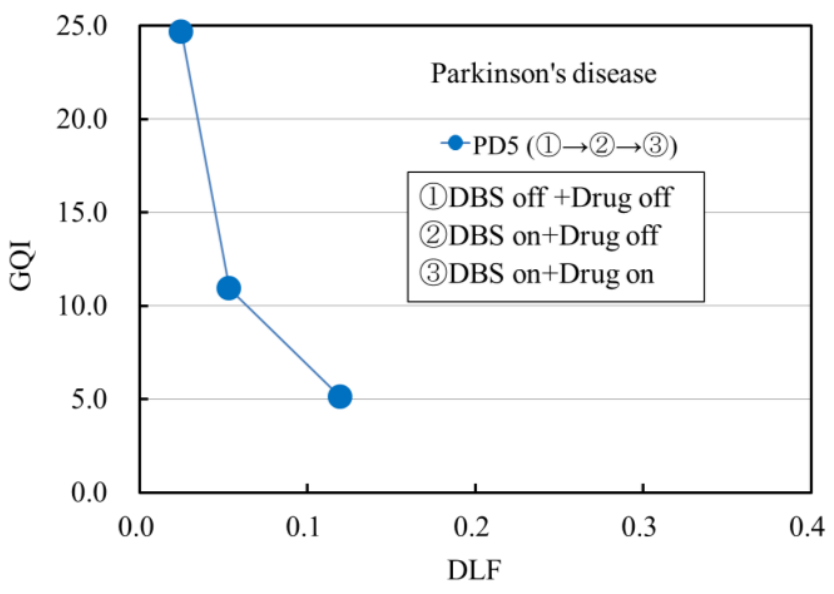

Fig. 17 Relationship between DLF and GQI in the vertical direction when a Parkinson's disease patient walks comfortably. It can be seen from this figure that the value of GQI decreases as DLF increases even more due to the effect of DBS (Deep Brain Stimulation).

\section{5. まとめ}

本研究は，健常者と跛行患者の正中で観測した加速度（体幹加速度）をFFTでスペクトル解析し，歩容改善の 定量的評価を試みたものである．得られた主要な結果を以下にまとめる.

（1）鉛直方向のパワースペクトルを用いて，10Hzまでの合計值を歩調成分（fw成分）の值で除した数值を，歩行 の質を表す指標GQIと定義した.

（2）健常者の GQI を算出したところ, DLF の大きさが 0.1 から 0.4 の範囲では, $1.3 \leqq G Q I \leqq 2.0$ 程度であった.

（3）正中で計測した片麻痺患者の鈆直方向加速度を対象として，DLFとGQIの相関図を作成した．その結果，歩容 が改善してDLFが増加すれば, 歩調成分（fw成分）のパワーが増加（歩調以外の成分が占めるパワーが低下）し， 
歩行の質を表す指標GQIが改善（数值としては低減）することがわかった．また，GQIは，シューホーンブレー スなどの下肢装具の選定作業においても，有用な評価指標になり得ると考えられた.

(4) 片麻痺患者に対しては, 前後方向の加速度波形に対してGQI を算出しても DLF との相関が認められた. ただ し，DLF に対する GQI の変化割合は鉛直方向の方が明らかに大きく，歩行指標としては鉛直方向の GQI を適用 した方が有用である.

(5) 前後方向の PR 值（=fw 成分に対する $0.5 f w$ 成分のパワースペクトル比）と左右方向の横変位（0.5fw 成分）に 対する DLF の依存度は, 鉛直方向の GQI と比較して幾分小さく, これら 2 つはそれぞれ独立の歩行評価指標と

して採用すればと良いと考えられる。

（6）THA術後患者, 大腿骨骨折患者, 前十字勒帯損傷患者, パーキンソン病患者の歩行実験結果についても, DLF とGQIの相関図を作成した，その結果，片麻痺患者と同様に，歩容が改善してDLFが増加すれば，歩調成分のパ ワーが増加（歩調以外の成分が占めるパワーが低下）し，歩行の質を表す指標GQIが改善（低減）することがわ かった.

以上より, 本研究で提示したDLFとGQIの相関図を作成する手法は，すでに提案している歩行評価指標（DLF， $\mathrm{PR} と \mathrm{GS}$ ，横変位，歩調）と同様に，あらゆる跛行患者の歩容評価に適用できる可能性が高く，歩行リハビリテ ーションに有意義な情報を与えるものと思われる，それゆえ，今後は，変形性股関節症患者や人工膝関節術後患 者なども含めて適用事例を増やし，提案した評価指標の有用性を検討していく所存である.

\section{文献}

Dallard, P., Fitzpatrick, A. J., Flint, A., Le Bourva, S., Low, A., Ridsdill Smith, R. M. and Willford, M., The London Millennium Footbridge, The Structural Engineer, Vol.79, No.22(2001), pp.17-33.

池㴊充彦, 岩城啓好, 箕田行秀, 高岡邦夫, 中土 保, 加藤良一, 今久保伸二, 赤坂波子, 中島重義, Wearable 加速 度計を用いた変形性股関節症患者における離散コサイン変換による歩行解析, 日本臨床バイオメカニクス学 会誌, Vol.29(2008), pp.325-329.

加賀谷 斉, 渡辺章由, 松田文浩, 加藤洋平, 失調の簡易動作解析, リハビリテーション医学, Vol.47, No.9(2010), pp.612-614.

香川真二, 千田 廉, 木村愛子, 前田真依子, 眞㴊 敏, 道免和久, リサージュ図形を用いた歩行加速度データの 可視化評価の開発と臨床的有用性, 理学療法学, Vol.36, No.1(2009), pp18-23.

梶川康男, 振動感覚を考慮した歩道橋の使用性照査法に関する研究, 土木学会論文報告集, No.325(1982), pp.2333.

小堀為雄，梶川康男，城戸隆良，振動感覚を考慮した歩道橋の設計，橋梁と基礎，Vol.8, No.12(1974), pp.23-29.

Mårtensson, A. and Nilsson, M., Dynamic analysis of pedestrian load models for footbridges, A review of current load models and guidelines, Chalmers University of Technology, Master's thesis(2014), pp.1-270.

Murray, T. M., Allen, D. E. and Ungar, E. E., Floor vibrations due to human activity, Steel design guide series, Vol. 11, American institute of structural construction (2003), pp. 1-69.

南角 学, 神先秀人, 石倉 隆, 川那辺圭一, 中村孝志, 術後早期における人工股関節全置換術後患者の歩行分析 -歩行中の股関節伸展角度の減少が重心移動に及ぼす影響-, 理学療法科学, Vol.20, No.2(2005), pp.121-125.

Picelli, A., Camin,M., Tinazzi,M., Vangelista,A., Cosentino,A., Fiaschi,A. and Smania,N., Three-dimensional motion analysis of the effects of auditory cueing on gait pattern in patients with Parkinson's disease: a preliminary investigation, Neurological Sciences,Vol.31(2010), DOI:10.1007/s10072-010-0228-2.

重枝利佳, 山本澄子, 石井慎一郎, 牧田浩行, 人工股関節全置換術後患者の歩行分析-術後 12 ヶ月間の追跡調査-, 理学療法科学, Vol.29, No.4(2014), pp.609-613.

田中尚文, 園田 茂, 村岡慶裕, 富田 豊, 千野直一, 小型加速度計による歩行分析の再現性および妥当性の検討, リハビリテーション医学, Vol.33, No.8(1996), pp.549-553.

米田昌弘, 加速度波形のパワースペクトルを用いた歩行者の歩行特性簡易算定法, 土木学会論文集 A1（構造・地 震工学) , Vol.67, No.3(2011), pp.539-544.

米田昌弘，パワースペクトルを用いた鈶直歩行外力の算定とその高次成分の評価，構造工学論文集， Vol.59A(2013), pp.332-339. 
米田昌弘, 歩行外力の高次成分に起因した歩道橋の鉛直振動, 構造工学論文集, Vol.61A(2015), pp.153-162.

米田昌弘, リハビリテーション医療への適用を考えた片麻瘒歩行の定量的評価手法に関する研究, 日本機械学会 論文集, Vol.82, No.839(2016), DOI: 10.1299/transjsme.16-00008.

米田昌弘, 福田寛二, 大井通正, 三橋亜由美, 西田篤司, 松田昌弘, 系数万紀, 腰部加速度波形のスペクトル解析 結果を用いた片麻㿁患者の歩行分析とその定量的評価指標，日本機械学会論文集，Vol.84，No.865(2018), DOI:10.1299/tranjsme.18-00238.

米田昌弘, 池㴊充彦, 福田寛二, 加藤良一, 中土 保, 中島重義, 中村博亮, 体幹加速度のスペクトル解析結果を 用いた人工股関節全置換術後患者の歩容解析, 日本機械学会論文集, Vol.85, No.877(2019), DOI:10.1299/tranjsme.19-00103.

\section{References}

Dallard, P., Fitzpatrick, A. J., Flint, A., Le Bourva, S., Low, A., Ridsdill Smith, R. M. and Willford, M., The London Millennium Footbridge, The Structural Engineer, Vol.79, No.22(2001), pp.17-33.

Ikebuchi, M., Iwaki,H., Minoda,Y., Takaoka,K., Nakatsuchi,T., Kato,R., Imakubo,S., Akasaka,N. and Nakajima,S., Gait analysis by discrete cosine transform (DCT) in patients with osteoarthritis of the hip using a wearable accelerometer, Japanese Journal of Clinical Biomechanics, Vol.29(2008), pp.325-329 (in Japanese).

Kagaya, H., Watanabe, A., Matsuda, F. and Kato,Y., Simple motion analysis for ataxia patients, The Japanese journal of rehabilitation medicine, Vol.47,No.9(2010),pp612-614(in Japanese).

Kagawa, S., Chida, Y., Kimura, A., Maeda, M., Mabuchi, S. and Domen, K., Development of visual evaluation of gait acceleration data with lissajous figure:utility for rehabilitation,Japanese physical therapy association, Vol.36,No.1(2009), pp18-23 (in Japanese).

Kajikawa, Y., Some considerations on ergonomical serviceability analysis of pedestrian bridge vibrations, Proceedings of Japan Society of Civil Engineers, No.325(1982), pp.23-33 (in Japanese).

Kobori, T.,Kajikawa, Y. and Kido, T., Pedestrian bridge design based on human vibration sensibility, Bridge and Foundation Engineering, Vol.8,No.12(1974),pp.23-29(in Japanese).

Mårtensson, A. and Nilsson,M., Dynamic analysis of pedestrian load models for footbridges, A review of current load models and guidelines, Chalmers University of Technology, Master's thesis(2014), pp.1-270.

Murray, T. M., Allen, D. E. and Ungar, E. E., Floor vibrations due to human activity, Steel design guide series, Vol. 11, American institute of structural construction (2003), pp. 1-69.

Nankaku, M., Kanzaki, H., Ishikura, T., Kawanabe, K. and Nakamura, T., Gait analysis of patients in early after total hip arthroplasty surgery, Effects of reduced hip extension while walking on displacement of the center of gravity-,Journal of Physical Therapy Science, Vol.20, No.2(2005), pp.121-125(in Japanese).

Picelli, A., Camin, M., Tinazzi, M., Vangelista, A., Cosentino, A., Fiaschi, A. and Smania, N., Three-dimensional motion analysis of the effects of auditory cueing on gait pattern in patients with Parkinson's disease: a preliminary investigation, Neurological Sciences,Vol.31(2010), DOI:10.1007/s10072-010-0228-2.

Shigeeda, R., Yamamoto, S., Ishi,S. and Makita, H., Analysis of gait total hip arthroplasty patients:a one-year follw-up study, Journal of Physical Therapy Science, Vol. 29, No. 4(2014), pp.609-613(in Japanese).

Tanaka, N., Sonoda, S., Muraoka, Y., Tomita, Y. and Chino, N., Reproducibility and validity of gait analysis using portable accelerometer, The Japanese journal of rehabilitation medicine, Vol.33, No.8(1996), pp.549-553 (in Japanese).

Yoneda, M., A simplified method to identify human walking force based on the body response spectrum obtained by FFT analysis, Journal of Japan Society of Civil Engineers, Ser. A1 (Structural Engineering \& Earthquake Engineering), Vol.67, No.3(2011), pp.539-544 (in Japanese).

Yoneda, M., Some considerations on higher components of human walking vertical force measured by using FFT power spectrum, Journal of Structural Engineering, Vol.59A(2013), pp.332-339 (in Japanese).

Yoneda, M., Vertical vibration of pedestrian bridge induced by higher components of human walking vertical force, Journal of Structural Engineering \& Earthquake Engineering, Vol.61A(2015), pp.153-162 (in Japanese).

Yoneda,M., A study on quantitative evaluation method for hemiplegic gait from the viewpoint of application to medical rehabilitation, Transactions of the JSME(in Japanese), Vol.82, No.839(2016), DOI: 10.1299/transjsme.16-00008.

Yoneda, M., Fukuda, K., Oi, M., Mitsuhashi, A., Nishida, A., Matsuda, M. and Itokazu, M., Quantitative evaluation indices 
Yoneda, Fukuda, Ikebuchi, Inoue, Oi, Mitsuhashi, Nishida, Matsuda, Murakami and Itokazu, Transactions of the JSME (in Japanese), Vol.86, No.886 (2020)

for hemiplegic gait characteristics based on power spectrum density for time history signals measured by accelerometers attached to the lumbar part, Transactions of the JSME(in Japanese), Vol.84, No.862(2018), DOI:10.1299/tranjsme.18-00238.

Yoneda, M., Ikebuchi, M., Fukuda, K., Kato, R., Nakatsuchi, T., Nakajima, S. and Nakamura, H., Gait analysis of total hip arthroplasty patients based on the spectral analysis results of trunk acceleration, Transactions of the JSME(in Japanese), Vol.85,No.877(2019), DOI:10.1299/tranjsme.19-00103. 